\title{
Alteration of primary Cr-spinel mineral composition from the Suru Valley ophiolitic peridotites, Ladakh Himalaya: Their low-temperature metamorphic implications
}

\author{
I M Bhat ${ }^{1, *}$, T Ahmad ${ }^{2}$ and D V SubBa RAO ${ }^{3}$ \\ ${ }^{1}$ Department of Earth Sciences, University of Kashmir, Srinagar 190 006, India. \\ ${ }^{2}$ Vice Chancellors Office, University of Kashmir, Srinagar 190 006, India. \\ ${ }^{3}$ Geochemistry Division, National Geophysical Research Institute (NGRI), Hyderabad 500 606, India. \\ *Corresponding author. e-mail: imbhat89@gmail.com
}

MS received 14 November 2018; revised 24 April 2019; accepted 25 April 2019; published online 5 July 2019

The present study focuses on the chemical modification of a Cr-spinel from the Suru Valley ophiolitic peridotites exposed near Trespone Village of Kargil district, Ladakh Himalaya. The Suru Valley peridotite is partially serpentinised with the preservation of the spinel and relics of olivine and pyroxene. These peridotites contain characteristic red-brown spinel grains of corroded grain boundaries. While analysing these grains for mineral chemistry, compositional variation was observed with Cr-rich cores rimmed by Cr-poor compositions. Secondary spinel compositions, i.e., ferritchromite and magnetite were observed along the margins and cracks of primary Cr-spinel grains. The primary $\mathrm{Cr}$-spinel cores are identified as Cr-rich and are characterised by higher values of $\mathrm{Cr}^{3+} \#(0.5-0.6)$ and lower values of $\mathrm{Al}^{3+} \#$ (0.42-0.54). From primary spinel cores to altered rims it was observed that $\mathrm{Cr}^{3+} \#$ and $\mathrm{Fe}^{3+} \#$ increase while $\mathrm{Mg}^{2+} \#$ decreases due to $\mathrm{Mg}^{2+}-\mathrm{Fe}^{2+}$ and $\mathrm{Al}^{3+}-\mathrm{Fe}^{3+}$ exchange with surrounding silicates of host peridotite during alteration. On the basis of present spinel mineral chemistry, metamorphic alteration conditions were transitional between greenschist and lower amphibolite similar to most of the Neo-Tethyan ophiolite peridotites.

Keywords. Indus suture zone; Suru Valley ophiolite; peridotites; metamorphism; Cr-spinel.

\section{Introduction}

The mineral assemblage of ophiolite peridotites cropped out at the surface of the Earth provides imperative information regarding the geochemical and geodynamic evolution of the upper mantle (Dai et al. 2011, 2013; Uysal et al. 2012; Khedr et al. 2014). The compositional variation of a chromium spinel [Cr-spinel; $(\mathrm{Mg}$, $\left.\left.\mathrm{Fe}^{2+}\right)\left(\mathrm{Cr}, \mathrm{Al}, \mathrm{Fe}^{3+}\right)_{2} \mathrm{O}_{4}\right]$ is poorly known from these low-temperature metamorphosed ophiolite mafic-ultramafic rocks (Sack and Ghiorso 1991; Barnes 2000).

Primary minerals such as olivine and pyroxene in ophiolite mantle peridotites are usually altered to secondary low-temperature minerals (e.g., serpentine, chlorite); however, the Cr-spinel is the only preserved primary mineral even in completely serpentinised peridotites (Arai 1994a). Therefore, the study of its mineral chemistry is useful to understand the petrogenetic processes of host peridotites (Irvine 1965, 1967; Dick and Bullen 
1984; Arai 1992, 1994a, b; Ahmed et al. 2001, 2005; Proenza et al. 2004; Farahat 2008; Aswad et al. 2011; Singh and Singh 2011; Colas et al. 2014, 2016; Bhat et al. 2017b). During low-temperature alteration, the change in chemistry of the primary Crspinel results in secondary mineral formation, i.e., $\mathrm{Fe}-\mathrm{Cr}$ spinels also called ferritchromite and/or magnetite depends on the degree of alteration (Arai 1978). Despite secondary origin these ferritchromites actually have chemical characteristics of primary mantle Cr-spinels (Arai et al. 2006).

The purpose of the present paper is to describe the chemical variation of accessory primary Cr-spinels from Suru Valley ophiolitic peridotites and their low-temperature alteration implications.

\section{Geology and petrography}

The Ladakh Himalaya, marks the northern position in the Alpine-Himalayan Orogen, was formed due to collision between two major continental landmasses India on south and Eurasia on north during Cenozoic Era (Gansser 1964, 1980; Frank et al. 1977; Srikantia and Razdan 1980; Brookfield and Reynolds 1981; Honegger et al. 1982; Deitrich et al. 1983; Searle et al. 1987; Aitchison et al. 2000; Maheo et al. 2004; Ahmad et al. 2008 and references therein). The Neo-Tethys Ocean once separating Indian and Eurasian landmasses during Mesozoic start closing by the initiation of intraoceanic island arcs thereby collision between continental margins and created suture zones outlined by ophiolites (Gansser 1980; Searle et al. 1987; Aitchison et al. 2000, 2002, 2007; Clift et al. 2002; Maheo et al. 2004, 2006; Ahmad et al. 2008; Buckman et al. 2018). These ophiolite slices are distributed along the Indus Suture Zone (ISZ) as dismembered ophiolite slices and from south-east to north-west are Nidar ophiolite sequence (Maheo et al. 2004; Ahmad et al. 2008), Spongtang ophiolite (Clift et al. 2002; Maheo et al. 2004; Buckman et al. 2018 and reference therein), Shergol ophiolitic slice (Honegger et al. 1989; Sinha and Mishra 1992, 1994; Maheo et al. 2006; Bhat et al. 2017a, b, 2018), Suru Valley ophiolitic slice (Reuber 1989; Robertson 2000; Bhat et al. 2019a) and Dras ophiolite (Radhakrishna et al. 1984, 1987). The Indus ophiolite belt extends westward to Pakistan, Iraq, Iran up to Turkey and eastward to Tibet, Nagaland-Manipur up to Indonesia (Hall 1997; Bortolotti and Principi 2005; Dilek and
Furnes 2009) and these ophiolites are classified as Tethyan type ophiolites by Moores et al. (2000). Based on the radiometric age data and fossil record these ophiolitic slices are Mesozoic in age (Reuber et al. 1990; Aitchison et al. 2000; Maheo et al. 2004; Ahmad et al. 2008; Buckman et al. 2018). A supra-subduction zone setting of these ophiolites is commonly recognised based on the bulk rock geochemistry and mineral chemistry (Robertson 2000; Sachan 2001; Maheo et al. 2004, 2006; Ahmad et al. 2008; Buckman et al. 2018; Bhat et al. 2019a).

The regional geology of the study area is described in detail in our published papers (Bhat et al. 2017a, b, 2018, 2019a, b and references therein), here we explain the geological setup of the Suru Valley ophiolitic slice. The present peridotite samples were obtained from the Suru Valley ophiolitic slice along ISZ, outcropped at Trespone village of Kargil district Ladakh Himalaya (figure 1). The Suru Valley ophiolitic slice is mainly composed of peridotite of mantle origin serpentinised to various degrees and shows affinity towards alpinetype peridotites as compared to layered-igneous complexes (Bhat et al. 2019a).

These ophiolitic peridotites contain serpentine pseudomorphs after olivine, bastites after pyroxene (figure 2a) and subhedral-anhedral primary spinel grains (figure 2b). They show pseudomorphic and interpenetrating textures besides, mesh and hourglass texture were also observed. The serpentine pseudomorph after olivine is mainly chrysotile and/ or lizardite in studied serpentinised peridotites (figure 2a). The presence of the bastite pseudomorph after orthopyroxene reflects harzburgite as protolith (Arai et al. 2006) which is also confirmed by their major and trace element geochemistry (Bhat et al. 2019a). Also the anhedral shape of the Cr-spinel and the stout shape of bastites reflect proto-granular texture of the protolith. Serpentine and magnetite are the main metamorphic byproducts after primary silicates (figure 2a). The primary red-brown Cr-spinels are characterised by zoning with darker cores of low reflectance compared to a light grey outer rim with high reflectance (figure 2c). The Cr-spinel polished surfaces under a scanning electron microscope (SEM) show two different reflectivities with a sharp optical boundary; the core region has low reflectivity while the rim region has high reflectivity (figure $2 \mathrm{c}$ and $\mathrm{d}$ ). These secondary spinels with high reflectivity not only rim the primary Cr-spinel grains but also fill their cracks (figure $2 \mathrm{~d}$ ). 


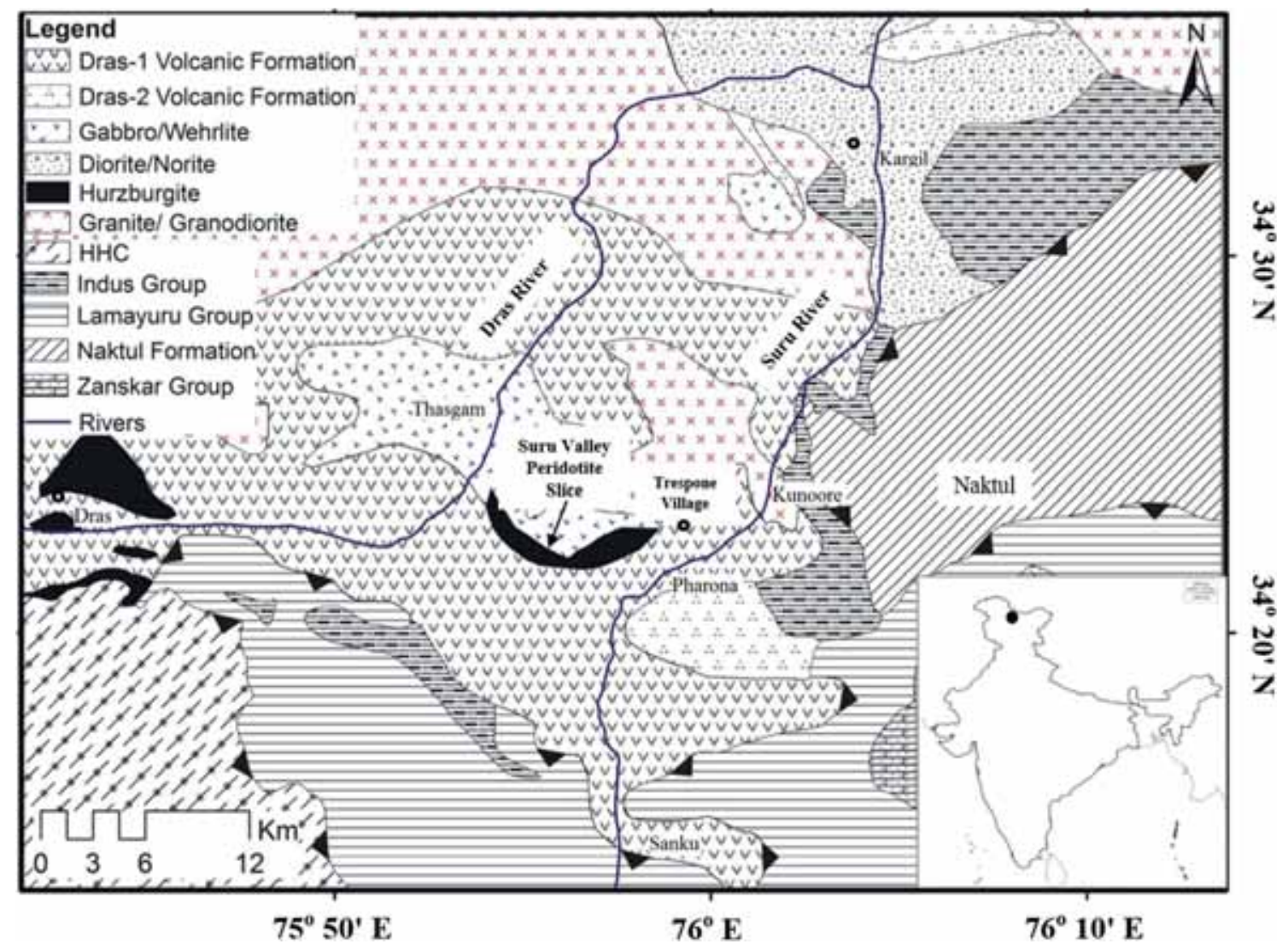

Figure 1. Geological map of Kargil district, NW Himalaya after Reuber (1989) showing location of the study area.

\section{Analytical technique}

A total of 18 thin sections from 10 samples of Suru Valley ophiolitic peridotites were examined under a polarising light microscope equipped with a digital camera at the department of Earth Sciences, University of Kashmir, Srinagar. A total of 36 mineral chemical analyses (three to four analyses from each sample) of the Cr-spinel were performed using an electron probe micro analyser (EPMA) CAMECA SX-Five instrument at the Banaras Hindu University, Varanasi, India. The CAMECA SX-Five Instrument was operating on a $15 \mathrm{kV}$ accelerating voltage and 10-20 nA probe beam current at a diameter of $1 \mu \mathrm{m}$. Quality control was maintained by analysing well calibrated natural mineral standards (chromite for $\mathrm{Cr}$, haematite for $\mathrm{Fe}$ and $\mathrm{NiO}$ for $\mathrm{Ni}$ ) during each electron microprobe session. The proportion of ferrous and ferric iron in spinels was calculated by assuming spinel stoichiometry. Routine X-ray spectral analysis (calibration, acquisition and quantification) and data processing were carried out using SxSAB version 6.1 and SX-Results software of CAMECA and replicate analyses of individual points show an analytical error of $<2 \%$.

\section{Results}

Electron microprobe data of the secondary spinel minerals i.e., ferritchromite and magnetite from the Suru Valley ophiolitic peridotites are given in tables 1 and 2, respectively. For the primary Crspinel composition we have used our published data from Bhat et al. (2019a). In accessory spinel grains from studied peridotites, three different compositional zones from the core to rim were observed by EPMA studies, which are: (i) core zones of primary chromite (i.e., Cr-spinel) composition, (ii) the intermediate ferritchromite (or ferrian chromite) zone and (iii) the rim of magnetite (figure 2). These zones from the core to rim are characterised by a significant increase in $\mathrm{Fe}^{3+}$ and $\mathrm{Fe}^{2+}$, and a decrease in $\mathrm{Mg}$ and $\mathrm{Al}$. The Cr-spinel core composition of the studied peridotites is characterised by high $\mathrm{Cr}_{2} \mathrm{O}_{3}$ (35.11-43.43 wt\%), low $\mathrm{Al}_{2} \mathrm{O}_{3}$ (22.42-30.41 wt\%), FeO (14.33-19.83 wt\%) and $\mathrm{MgO}(9.28-13.51$ wt\%). Their Cr number $\left[\mathrm{Cr}^{3+} \#\right.$ : cationic ratio of $\left.\mathrm{Cr}^{3+} /\left(\mathrm{Cr}^{3+}+\mathrm{Al}^{3+}\right)\right]$, $\mathrm{Mg}$ number $\left[\mathrm{Mg}^{2+} \#\right.$ : cationic ratio of $\mathrm{Mg}^{2+} /$ $\left.\left(\mathrm{Mg}^{2+}+\mathrm{Fe}^{2+}\right)\right]$ and $\mathrm{Al}$ number $\left[\mathrm{Al}^{3+} \#\right.$ : cationic ratio of $\left.\mathrm{Al}^{3+} /\left(\mathrm{Cr}^{3+}+\mathrm{Al}^{3+}+\mathrm{Fe}^{3+}\right)\right]$ ranges from 


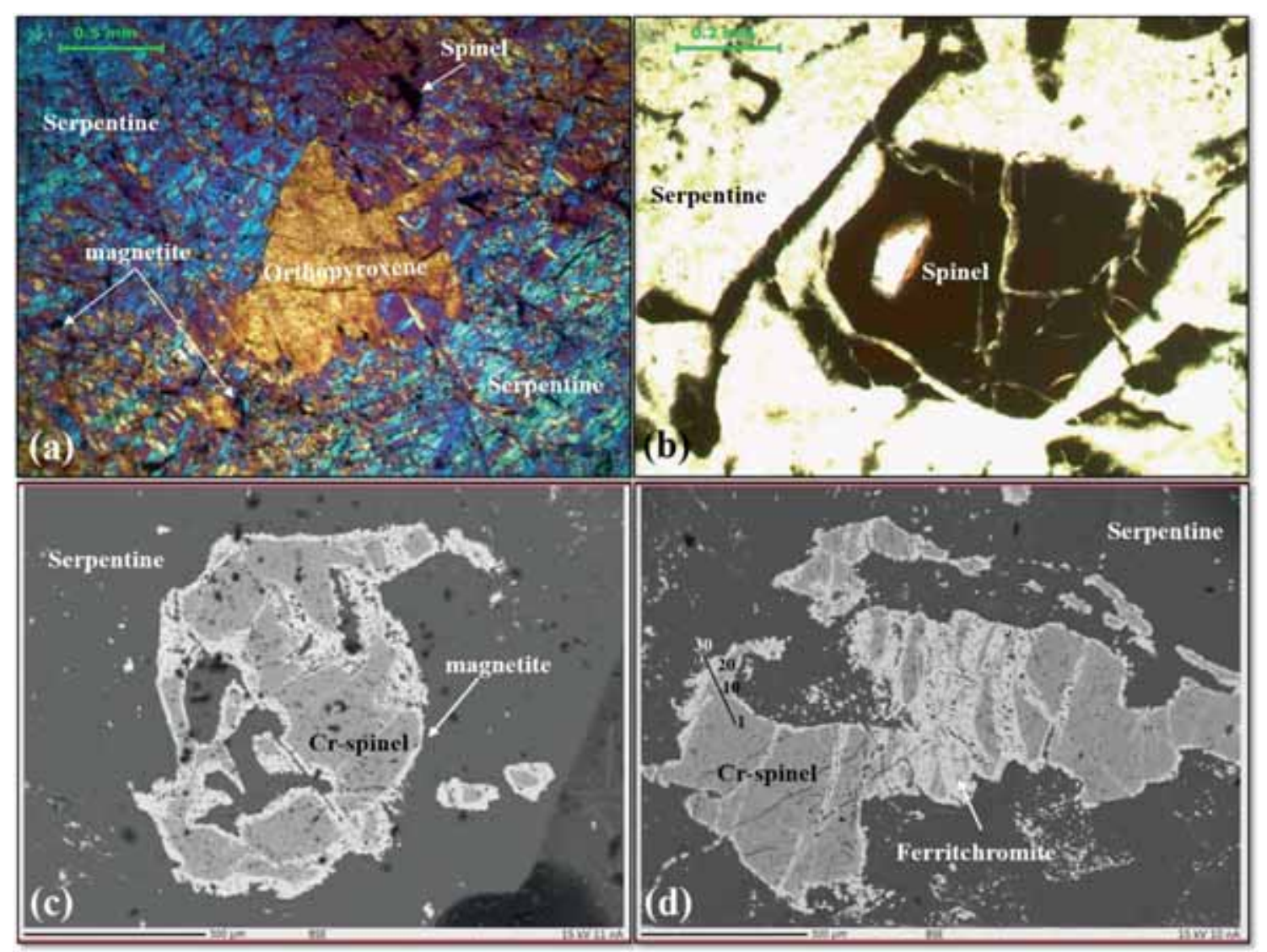

Figure 2. Photomicrograph and back-scattered electron (BSE) images of Suru Valley ophiolitic peridotites, western Ladakh Himalaya: (a) photomicrograph (under crossed polarised light) showing serpentine after primary olivine, orthopyroxene bastite, accessory spinels and secondary magnetite; (b) photomicrograph (under reflected light) showing serpentine after olivine and fractured subhedral spinel grain; (c) BSE-image showing zoned Cr-spinel grain with a low-reflectance core of Cr-spinel composition and high-reflectance rim of magnetite composition; and (d) BSE-image showing partly altered primary Cr-spinel grain with a metamorphic spinel of ferritchromite composition.

0.5 to $0.6,0.4$ to 0.5 and 0.5 to 0.6 , respectively (Bhat et al. 2019a). Also, the $\mathrm{Al}_{2} \mathrm{O}_{3}$ concentration ranges from 1.01 to 1.75 whereas $\mathrm{TiO}_{2}$ is $<0.06$ wt\% (Bhat et al. 2019a).

In the studied peridotites, the relic olivine grains range in composition from $\mathrm{FO}_{90}-\mathrm{FO}_{92}$ and are similar to the primary olivine relics of ophiolitic peridotites (meta-ultramafics) from the south Eastern Desert (SED), Egypt (Fo89-96 after Khudeir 1995; Khalil and Azer 2007; Khedr and Arai 2013; Obeid et al. 2016), Fawakhir area of Central Eastern Desert (CED), Egypt $\left(\mathrm{Fo}_{89-92}\right.$ after Abdel-Karim et al. 2018) and Spongtang ophiolite peridotites $\left(\mathrm{FO}_{87-92}\right.$ after Jonnalagadda et al. 2019). This olivine chemistry corresponds to chrysotile and/or forsterite composition (Dick and Bullen 1984). Also, the $\mathrm{Mg}$ number $\left[\mathrm{Mg}^{2+} \#\right.$ : cationic ratio of $\left.\mathrm{Mg}^{2+} /\left(\mathrm{Mg}^{2+}+\mathrm{Fe}^{2+}\right)\right]$ of olivine is high and ranges from 0.90-0.92 (Bhat et al. 2019a). The relic orthopyroxene of enstatite composition
$\left(\mathrm{En}_{91-93} \mathrm{Fs}_{7-9}\right)$ is highly magnesian in nature with $\mathrm{Mg}^{2+}$ \# varies from 0.91 to 0.93 similar to Spongtang peridotites $\left(\mathrm{En}_{89-90}, \mathrm{Fs}_{9-10}\right.$ after Jonnalagadda et al. 2019).

The studied Cr-spinel compositions from the Suru Valley peridotites when plotted in the $\mathrm{Al}^{3+}-\mathrm{Cr}^{3+}-\mathrm{Fe}^{3+}$ ternary diagram characterise three compositional varieties i.e., Cr-spinel, ferritchromite and magnetite (figure 3). The ferritchromite and magnetite rims mantling the Cr-spinel cores are the alteration/metamorphic products of primary $\mathrm{Cr}$-spinel and are highly depleted in $\mathrm{Mg}^{2+}$ and $\mathrm{Al}^{3+}$ as compared to $\mathrm{Cr}$ spinel cores. Similarly, relative to Cr-spinel core composition, ferritchromite has slight depletion of $\mathrm{Cr}^{3+}$ compared with that of magnetite which shows more depletion. The only cations i.e., $\mathrm{Fe}^{2+}$ and $\mathrm{Fe}^{3+}$ are significantly enriched at the rim (i.e., magnetite) compared to the unaltered core 
Table 1. Representative electron-microprobe analyses of ferritchromite (rim composition) from Suru Valley peridotites along ISZ, NW Ladakh Himalaya (calculation based on 32 oxygen).

\begin{tabular}{|c|c|c|c|c|c|c|c|c|c|c|}
\hline Points & P-286 & P-287 & P-288 & P-301 & P-203 & P-208 & $\mathrm{P}-237$ & $\mathrm{P}-247$ & P-249 & P-252 \\
\hline $\mathrm{SiO}_{2}$ & 0.03 & 0.03 & 0.06 & 0.07 & 0.16 & 0.85 & 0.02 & 0.11 & 0.41 & 0.07 \\
\hline $\mathrm{TiO}_{2}$ & 0.22 & 0.21 & 0.22 & 0.23 & 0.01 & 0.02 & 0.39 & 0.36 & 0.37 & 0.30 \\
\hline $\mathrm{Al}_{2} \mathrm{O}_{3}$ & 1.73 & 2.35 & 2.78 & 1.19 & 2.00 & 2.66 & 1.24 & 1.21 & 1.85 & 1.51 \\
\hline $\mathrm{Cr}_{2} \mathrm{O}_{3}$ & 22.46 & 21.49 & 21.13 & 20.53 & 27.68 & 26.21 & 28.53 & 24.40 & 29.45 & 28.32 \\
\hline $\mathrm{Fe}_{2} \mathrm{O}_{3}$ & 44.10 & 43.98 & 43.48 & 46.29 & 37.90 & 37.17 & 37.22 & 42.17 & 34.74 & 37.29 \\
\hline $\mathrm{FeO}$ & 29.81 & 29.60 & 29.48 & 29.47 & 27.07 & 28.49 & 25.76 & 27.51 & 26.67 & 24.95 \\
\hline $\mathrm{MnO}$ & 1.77 & 1.83 & 1.79 & 1.87 & 3.90 & 3.64 & 4.37 & 4.03 & 4.07 & 3.97 \\
\hline $\mathrm{MgO}$ & 0.21 & 0.11 & 0.34 & 0.22 & 0.52 & 0.45 & 0.86 & 0.29 & 0.76 & 1.54 \\
\hline $\mathrm{CaO}$ & 0.09 & 0.27 & 0.11 & 0.12 & 0.01 & 0.03 & 0.10 & 0.12 & 0.23 & 0.11 \\
\hline $\mathrm{ZnO}$ & 0.06 & 0.05 & 0.04 & 0.06 & 0.00 & 0.03 & 0.02 & 0.02 & 0.09 & 0.08 \\
\hline Total & 100.48 & 99.91 & 99.45 & 100.05 & 99.27 & 99.54 & 98.51 & 100.23 & 98.64 & 98.14 \\
\hline $\mathrm{Si}^{4+}$ & 0.01 & 0.01 & 0.02 & 0.02 & 0.05 & 0.25 & 0.01 & 0.03 & 0.13 & 0.02 \\
\hline $\mathrm{Ti}^{4+}$ & 0.05 & 0.05 & 0.05 & 0.05 & 0.00 & 0.00 & 0.09 & 0.08 & 0.08 & 0.07 \\
\hline $\mathrm{Al}^{3+}$ & 0.61 & 0.83 & 0.99 & 0.42 & 0.71 & 0.94 & 0.44 & 0.43 & 0.66 & 0.54 \\
\hline $\mathrm{Cr}^{3+}$ & 5.32 & 5.11 & 5.03 & 4.90 & 6.59 & 6.19 & 6.85 & 5.80 & 7.03 & 6.78 \\
\hline $\mathrm{Fe}^{3+}$ & 9.95 & 9.95 & 9.85 & 10.52 & 8.59 & 8.36 & 8.51 & 9.54 & 7.89 & 8.50 \\
\hline $\mathrm{Fe}^{2+}$ & 7.47 & 7.44 & 7.42 & 7.45 & 6.82 & 7.12 & 6.54 & 6.92 & 6.73 & 6.32 \\
\hline $\mathrm{Mn}^{2+}$ & 0.45 & 0.46 & 0.46 & 0.48 & 1.00 & 0.92 & 1.12 & 1.03 & 1.04 & 1.02 \\
\hline $\mathrm{Mg}^{2+}$ & 0.09 & 0.05 & 0.15 & 0.10 & 0.23 & 0.20 & 0.39 & 0.13 & 0.34 & 0.69 \\
\hline $\mathrm{Ca}^{2+}$ & 0.03 & 0.09 & 0.04 & 0.04 & 0.00 & 0.01 & 0.03 & 0.04 & 0.07 & 0.04 \\
\hline $\mathrm{Zn}^{2+}$ & 0.01 & 0.01 & 0.01 & 0.01 & 0.00 & 0.01 & 0.00 & 0.00 & 0.02 & 0.02 \\
\hline $\mathrm{Mg}^{2+} \#$ & 0.01 & 0.01 & 0.02 & 0.01 & 0.03 & 0.03 & 0.06 & 0.02 & 0.05 & 0.1 \\
\hline $\mathrm{Cr}^{3+} \#$ & 0.90 & 0.86 & 0.84 & 0.92 & 0.90 & 0.87 & 0.94 & 0.93 & 0.91 & 0.93 \\
\hline $\mathrm{Al}^{3+} \#$ & 0.04 & 0.05 & 0.06 & 0.03 & 0.05 & 0.06 & 0.03 & 0.03 & 0.04 & 0.03 \\
\hline $\mathrm{Fe}^{3+} \#$ & 0.63 & 0.63 & 0.62 & 0.66 & 0.54 & 0.54 & 0.54 & 0.61 & 0.51 & 0.54 \\
\hline $\mathrm{Fe}^{2+} \#$ & 0.99 & 0.99 & 0.98 & 0.99 & 0.97 & 0.97 & 0.94 & 0.98 & 0.95 & 0.90 \\
\hline
\end{tabular}

$\mathrm{Mg}^{2+} \#$ : cationic ratio of $\mathrm{Mg}^{2+} /\left(\mathrm{Mg}^{2+}+\mathrm{Fe}^{2+}\right) ; \mathrm{Cr}^{3+} \#$ : cationic ratio of $\mathrm{Cr}^{3+} /\left(\mathrm{Cr}^{3+}+\mathrm{Al}^{3+}\right) ; \mathrm{Al}^{3+} \#$ : cationic ratio of $\mathrm{Al}^{3+} /$ $\left(\mathrm{Cr}^{3+}+\mathrm{Al}^{3+}+\mathrm{Fe}^{3+}\right) ; \mathrm{Fe}^{3+} \#$ : cationic ratio of $\mathrm{Fe}^{3+} /\left(\mathrm{Fe}^{3+}+\mathrm{Cr}^{3+}+\mathrm{Al}^{3+}\right)$ and $\mathrm{Fe}^{2+} \#$ : cationic ratio of $\mathrm{Fe}^{2+} /\left(\mathrm{Fe}^{2+}+\mathrm{Mg}^{2+}\right)$.

(i.e., Cr-spinel). Also relative to the Cr-spinel core and magnetite rim, $\mathrm{Mn}$ and $\mathrm{Si}$ show enrichment in ferritchromite (table 1). These compositional discrepancies reflect diffusion of $\mathrm{Al}, \mathrm{Mg}$ and $\mathrm{Cr}$ and infusion of $\mathrm{Fe}, \mathrm{Mn}$ and $\mathrm{Si}$ with respect to the Cr-spinel core composition during alteration. This chemical variability in studied spinels further reflects the existence of two compositional miscibility gaps, one between the $\mathrm{Cr}-$ spinel core and ferritchromite zone and other between the ferritchromite zone and magnetite rim (figure 3).

The extensive $\mathrm{Mg}^{2+}-\mathrm{Fe}^{2+}$ divalent exchange between the coexisting spinel and silicate phases (e.g., olivine) in mantle peridotites results in decreasing $\mathrm{Mg}^{2+} \#$ from the Cr-spinel core through the ferritchromite to magnetite rim (figure 4a). Whereas due to $\mathrm{Al}^{3+}$ loss and $\mathrm{Fe}^{3+}$ enrichment during alteration of mantle peridotites, $\mathrm{Fe}^{3+} \#$ [cationic ratio of $\mathrm{Fe}^{3+} /\left(\mathrm{Fe}^{3+}\right.$ $\left.+\mathrm{Cr}^{3+}+\mathrm{Al}^{3+}\right)$ ] increases with decreasing $\mathrm{Mg}^{2+} \#$ from the Cr-spinel core to the magnetite rim (figure 4b).

The Cr-spinel in the studied peridotites has higher $\mathrm{Cr}^{3+} \#(>40)$ akin to that of ophiolitic peridotites of Bela, Muslimbagh-Zhob and Waziristan from Pakistan (Arif and Jan 2006), SED and CED from Egypt (Farahat et al. 2011; Ahmed et al. 2012; Abdel-Karim et al. 2016; Obeid et al. 2016) and Spongtang ophiolite from Ladakh Himalaya (Jonnalagadda et al. 2019). However, the Cr-spinel has lower $\mathrm{Cr}^{3+}$ than Tidding Suture Zone serpentinites from eastern Himalaya (Singh and Singh 2011) and higher than Manipur ophiolitic peridotites from IndoMyanmar orogenic belt (Singh 2009), Shergol ophiolitic peridotites from western Ladakh (Bhat et al. 2017b) and Kamyaran ophiolitic peridotites from Iran (Veisinia et al. 2018). Also, the studied Cr-spinel $\mathrm{TiO}_{2}$ and $\mathrm{Al}_{2} \mathrm{O}_{3}$ contents are comparable with supra-subduction zone peridotites and overlap with Spongtang and Nidar ophiolitic 
Table 2. Representative electron-microprobe analyses of magnetite (rim composition) from Suru Valley peridotites along ISZ, NW Ladakh Himalaya (calculation based on 32 oxygen).

\begin{tabular}{|c|c|c|c|c|c|c|c|c|c|c|}
\hline Points & P-112 & P-119 & P-296 & P-300 & P-181 & P-182 & $\mathrm{P}-24$ & P-55 & P-199 & P-200 \\
\hline $\mathrm{SiO}_{2}$ & 0.22 & 0.63 & 0.05 & 0.78 & 0.59 & 0.45 & 0.06 & 0.29 & 0.56 & 0.09 \\
\hline $\mathrm{TiO}_{2}$ & 0.04 & 0.05 & 0.19 & 0.18 & 0.04 & 0.03 & 0.14 & 0.16 & 0.13 & 0.14 \\
\hline $\mathrm{Al}_{2} \mathrm{O}_{3}$ & 0.07 & 0.03 & 0.08 & 0.18 & 1.05 & 1.01 & 0.20 & 0.11 & 0.13 & 0.06 \\
\hline $\mathrm{Cr}_{2} \mathrm{O}_{3}$ & 1.16 & 1.31 & 1.01 & 1.66 & 0.05 & 0.06 & 1.06 & 1.17 & 0.16 & 0.23 \\
\hline $\mathrm{Fe}_{2} \mathrm{O}_{3}$ & 68.19 & 65.74 & 67.86 & 65.41 & 66.75 & 66.80 & 67.70 & 66.32 & 66.57 & 67.70 \\
\hline $\mathrm{FeO}$ & 30.24 & 31.28 & 31.07 & 32.18 & 30.86 & 30.97 & 31.22 & 30.89 & 30.57 & 30.61 \\
\hline $\mathrm{MnO}$ & 0.17 & 0.07 & 0.15 & 0.12 & 0.02 & 0.07 & 0.00 & 0.00 & 0.03 & 0.02 \\
\hline $\mathrm{MgO}$ & 0.75 & 0.05 & 0.07 & 0.04 & 0.71 & 0.36 & 0.10 & 0.15 & 0.45 & 0.11 \\
\hline $\mathrm{CaO}$ & 0.05 & 0.03 & 0.11 & 0.13 & 0.09 & 0.12 & 0.05 & 0.13 & 0.21 & 0.19 \\
\hline $\mathrm{ZnO}$ & 0.08 & 0.38 & 0.03 & 0.00 & 0.02 & 0.09 & 0.03 & 0.15 & 0.02 & 0.03 \\
\hline Total & 100.95 & 99.57 & 100.62 & 100.69 & 100.17 & 99.96 & 100.56 & 99.37 & 98.83 & 99.18 \\
\hline $\mathrm{Si}^{4+}$ & 0.07 & 0.19 & 0.02 & 0.24 & 0.18 & 0.14 & 0.02 & 0.09 & 0.17 & 0.03 \\
\hline $\mathrm{Ti}^{4+}$ & 0.01 & 0.01 & 0.04 & 0.04 & 0.01 & 0.01 & 0.03 & 0.04 & 0.03 & 0.03 \\
\hline $\mathrm{Al}^{3+}$ & 0.02 & 0.01 & 0.03 & 0.07 & 0.38 & 0.36 & 0.07 & 0.04 & 0.05 & 0.02 \\
\hline $\mathrm{Cr}^{3+}$ & 0.28 & 0.32 & 0.24 & 0.40 & 0.01 & 0.01 & 0.26 & 0.29 & 0.04 & 0.06 \\
\hline $\mathrm{Fe}^{3+}$ & 15.55 & 15.26 & 15.61 & 14.98 & 15.24 & 15.33 & 15.57 & 15.42 & 15.51 & 15.80 \\
\hline $\mathrm{Fe}^{2+}$ & 7.66 & 8.07 & 7.94 & 8.19 & 7.83 & 7.90 & 7.98 & 7.98 & 7.91 & 7.94 \\
\hline $\mathrm{Mn}^{2+}$ & 0.04 & 0.02 & 0.04 & 0.03 & 0.00 & 0.02 & 0.00 & 0.00 & 0.01 & 0.01 \\
\hline $\mathrm{Mg}^{2+}$ & 0.34 & 0.02 & 0.03 & 0.02 & 0.32 & 0.17 & 0.04 & 0.07 & 0.21 & 0.05 \\
\hline $\mathrm{Ca}^{2+}$ & 0.02 & 0.01 & 0.04 & 0.04 & 0.03 & 0.04 & 0.02 & 0.04 & 0.07 & 0.06 \\
\hline $\mathrm{Zn}^{2+}$ & 0.02 & 0.09 & 0.01 & 0.00 & 0.00 & 0.02 & 0.01 & 0.03 & 0.00 & 0.01 \\
\hline $\mathrm{Mg}^{2+} \#$ & 0.04 & 0.03 & 0.01 & 0.02 & 0.04 & 0.02 & 0.01 & 0.01 & 0.03 & 0.01 \\
\hline $\mathrm{Cr}^{3+} \#$ & 0.92 & 0.96 & 0.92 & 0.96 & 0.96 & 0.90 & 0.92 & 0.92 & 0.92 & 0.96 \\
\hline $\mathrm{Al}^{3+} \#$ & 0.002 & 0.001 & 0.002 & 0.001 & 0.001 & 0.002 & 0.003 & 0.003 & 0.002 & 0.001 \\
\hline $\mathrm{Fe}^{3+} \#$ & 0.98 & 0.98 & 0.98 & 0.97 & 0.97 & 0.98 & 0.97 & 0.97 & 0.97 & 0.97 \\
\hline $\mathrm{Fe}^{2+} \#$ & 0.96 & 1.00 & 1.00 & 1.00 & 0.96 & 0.98 & 0.99 & 0.99 & 0.97 & 0.99 \\
\hline
\end{tabular}

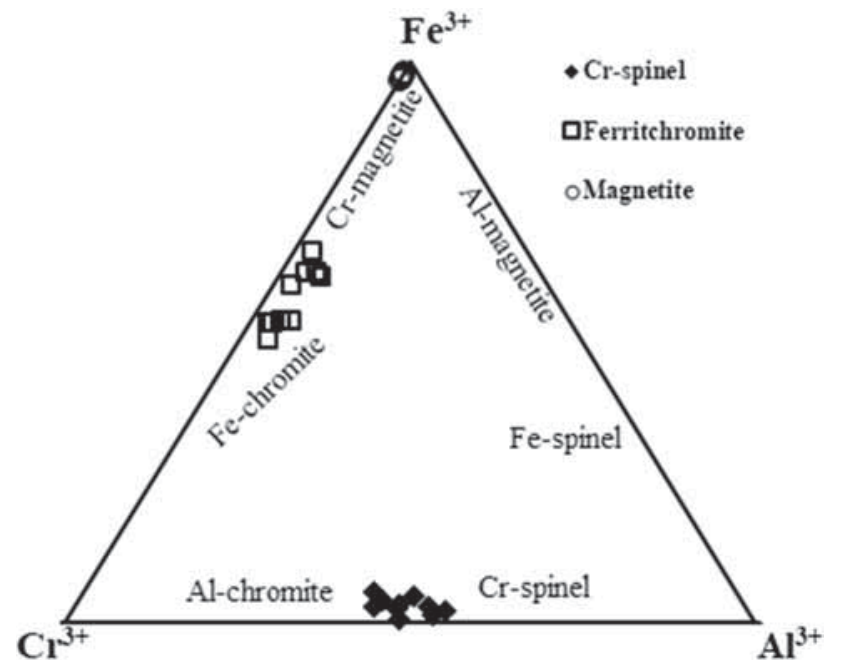

Figure 3. Triangular trivalent cation classification diagram showing the compositional variation of spinel grains from the Suru Valley ophiolitic peridotites, Ladakh Himalaya.

peridotites of Ladakh Himalaya (Maheo et al. 2004; Jonnalagadda et al. 2019) and Izu-Mariana arcs (Kamenetsky et al. 2001).

\section{Discussion and conclusion}

\subsection{Geochemical consequences due to alteration}

The Suru Valley ophiolitic peridotites from western Ladakh Himalaya have experienced serpentinisation - a low-grade hydrothermal metamorphism in the presence of serpentine and magnetite as a secondary mineral assemblage (Bhat et al. 2019a). Despite mineralogical modifications due to the serpentinisation process of mantle peridotites, geochemical studies on global peridotites show insignificant changes in the major elements (except for $\mathrm{Ca}, \mathrm{Na}, \mathrm{K}$ and to some extent $\mathrm{Mg}$ ) at the handspecimen scale (Mevel 2003; Niu 2004; Deschamps et al. 2010, 2013). Similarly, serpentinised peridotites specify insignificant modifications in the trace element compositions except $\mathrm{Rb}, \mathrm{Ba}, \mathrm{U}, \mathrm{Pb}$ and Sr (Niu 2004; Paulick et al. 2006; Deschamps et al. 2013). Recently, Bhat et al. (2019a) reported 5-8 wt\% MgO loss, the mobility of Fe, Ca, Na, K, $\mathrm{Rb}, \mathrm{Ba}, \mathrm{U}, \mathrm{Pb}, \mathrm{Sr}$, etc., the pristine characters of $\mathrm{Si}, \mathrm{Al}, \mathrm{Ti}$ and highly incompatible rare earth 

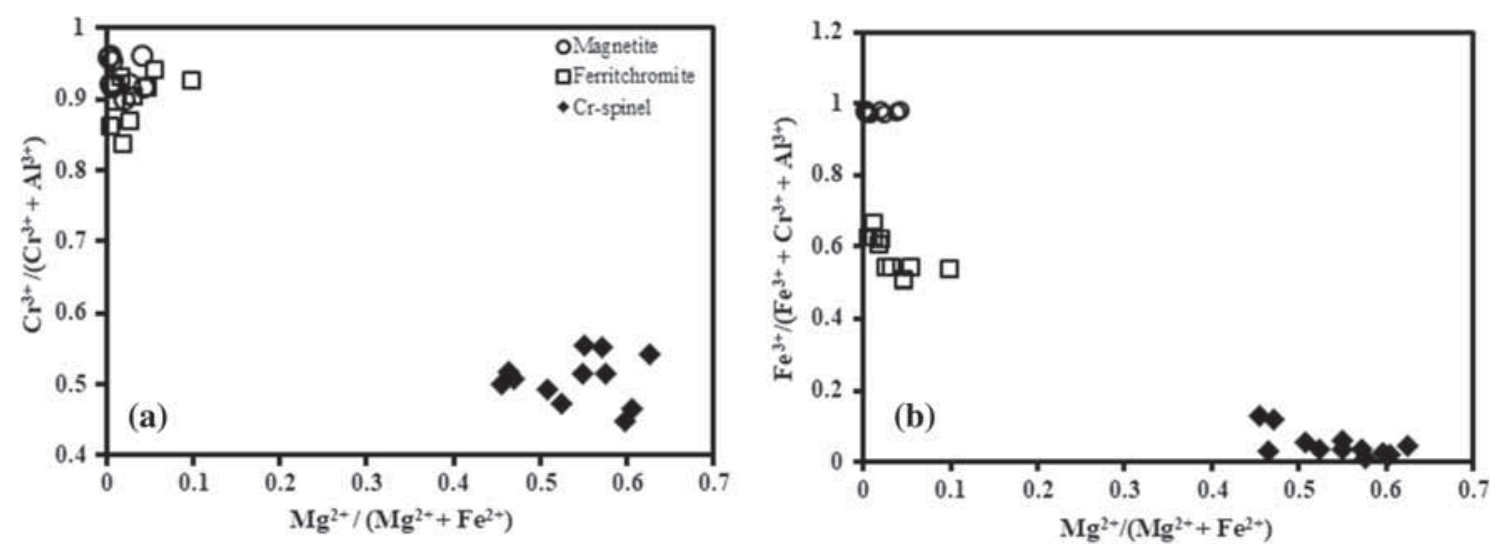

Figure 4. Suru Valley peridotite spinel composition plotted in (a) $\mathrm{Cr}^{3+} /\left(\mathrm{Cr}^{3+}+\mathrm{Al}^{3+}\right)$ against $\mathrm{Mg}^{2+} /\left(\mathrm{Mg}^{2+}+\mathrm{Fe}^{2+}\right)$ and (b) $\mathrm{Fe}^{3+} /\left(\mathrm{Fe}^{3+}+\mathrm{Al}^{3+}+\mathrm{Cr}^{3+}\right)$ against $\mathrm{Mg}^{2+} /\left(\mathrm{Mg}^{2+}+\mathrm{Fe}^{2+}\right)$.

and high-field strength elements in Suru Valley serpentinised with peridotites on the basis of bulk-rock major and trace element geochemistry.

Generally, in ophiolite peridotites the serpentinisation process leads to the alteration of a primary silicate mineral assemblage (Khudeir et al. 1992; Khalil and Azer 2007). Primary minerals like olivine and pyroxene may completely alter to serpentine, whereas the spinel is the only primary mineral that can preserve its composition even in completely serpentinised peridotites and may show zoning from the core to rim depending on the extent of the serpentinisation process and postserpentinisation metamorphism (Arai et al. 2006). According to Arai (1994b), the $\mathrm{Cr}^{3+} \#$ of the spinel in mantle peridotites appears to remain unchanged during the sub-solidus stage. Chromite alteration caused by fluid infiltration along cracks and grain boundaries during low-temperature metamorphism leads to the growth of Fe-enriched chromite i.e., ferritchromite (Barnes 2000; Farahat 2008). Further at higher temperature, fluid entrance gives rise to extensive magnetite replacement of chromite (Barnes 2000). In figure 3 the magnetite plots along the line joining $\mathrm{Cr}^{3+}-\mathrm{Fe}^{3+}$ closer to $\mathrm{Fe}^{3+}$ apex reflect $\mathrm{Fe}_{2} \mathrm{O}_{3}$ increase and loss of $\mathrm{Cr}_{2} \mathrm{O}_{3}$ and $\mathrm{Al}_{2} \mathrm{O}_{3}$ during alteration. Their high-ferric iron (i.e., $\mathrm{Fe}^{3+}$ ) reflects oxidation conditions during alteration (Anzil et al. 2012). The ferritchromites preserve high $\mathrm{Cr}_{2} \mathrm{O}_{3}$ (21-29 wt\%) close to those of unaltered Cr-spinel cores but have lower $\mathrm{Mg}^{2+}$ \# (0.01-0.1).

The secondary alteration/metamorphism typically imposes a chemical zoning on the primary spinel grains in the Suru Valley peridotites. The alteration of Cr-spinel composition (represented by 1-10 profile points in figure $2 \mathrm{~d}$ ) to ferritchromite (represented by 11-20 profile points in figure $2 \mathrm{~d}$ ) is characterised by a progressive enrichment in the total iron content $\left(\mathrm{Fe}^{3+}+\mathrm{Fe}^{2+}\right)$ and $\mathrm{Mn}$ (figure 5). However, the alterations are characterised by a strong depletion in $\mathrm{Al}, \mathrm{Cr}$ and $\mathrm{Mg}$ as compared with the relic Cr-spinel cores (figure 5a) and a negligible change in Ti (figure 5b). Similarly, the magnetite rims (represented by 21-30 profile points in figure 2d) show a strong systematic enrichment in $\mathrm{Fe}^{3+}$ and $\mathrm{Fe}^{2+}$ (figure 5a), whereas strong depletion in $\mathrm{Al}, \mathrm{Cr}, \mathrm{Mg}$ and $\mathrm{Mn}$ with respect to ferritchromite (figure 5). Therefore, compositional profiling across the studied spinel grains proves chemical variation from the core to rim as observed in other global peridotite spinels (e.g., Proenza et al. 2004; Karipi et al. 2007; Farahat 2008; Aswad et al. 2011; Singh and Singh 2011; Colas et al. 2014; Bhat et al. 2017b).

\subsection{Low-temperature metamorphic implications on spinel composition}

The compositional heterogeneity of the Cr-spinel is a function of the fluid-rock ratio and metamorphic grade (Barnes 2000; Farahat 2008). Therefore, post-magmatic hydrothermal metamorphism of host peridotites may cause chemical inconsistency in spinel mineral composition (Barnes 2000; Farahat 2008; Aswad et al. 2011). The Cr-spinel is the only reliable petrogenetic indicator in altered peridotites where all primary silicates were altered due to metamorphism (Ahmed et al. 2001, 2005). The alteration of the primary Cr-spinel results in the modification of its mineral chemistry in relation to the alteration of surrounding silicate minerals (Barnes 2000). The Cr-spinel in altered peridotites 


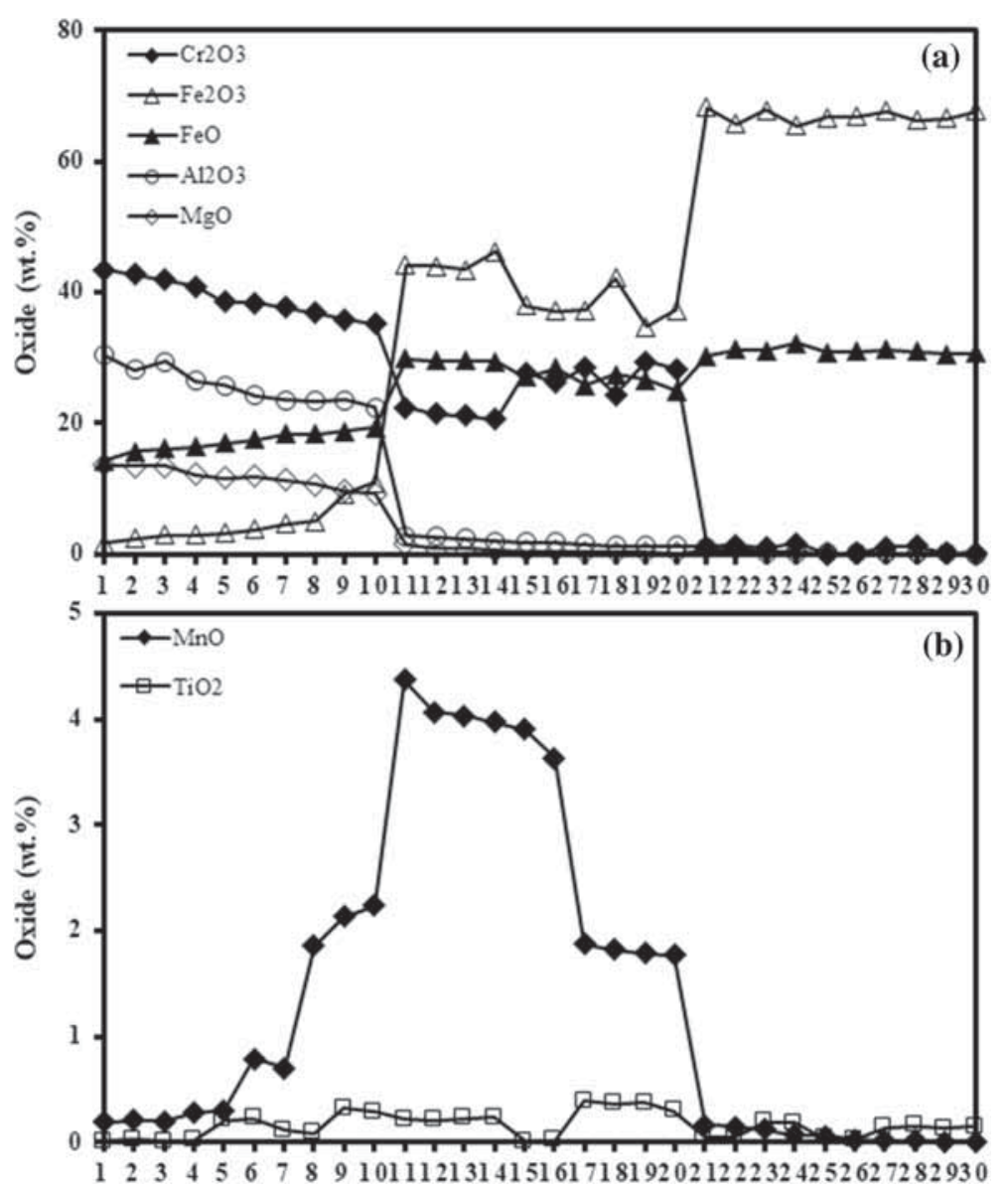

Figure 5. Compositional profile of electron-microprobe data across a compositionally zoned accessory Cr-spinel grain in Suru Valley peridotites: (a) $\mathrm{Cr}_{2} \mathrm{O}_{3}, \mathrm{Fe}_{2} \mathrm{O}_{3}, \mathrm{FeO}, \mathrm{Al}_{2} \mathrm{O}_{3}$ and $\mathrm{MgO}$ chemical variation along profile and $(\mathbf{b}) \mathrm{MnO}$ and $\mathrm{TiO} \mathrm{O}_{2}$ chemical variation along profile.

enhances its $\mathrm{Cr}^{3+} \#$ as well as magnetite component (both $\mathrm{Fe}^{2+}$ and $\mathrm{Fe}^{3+}$ ) to become so-called ferritchromite (Arai et al. 2006). This secondary spinel with high $\mathrm{Cr}^{3+} \#$ and low $\mathrm{Fe}^{3+} \#$ can be achieved by the removal of $\mathrm{Al}$ without $\mathrm{Fe}$ addition (Barnes 2000; Arai et al. 2006).

As described, the studied spinel grains show systematic compositional variation along their rims or through cracks from the Cr-spinel to ferritchromite or from the Cr-spinel to magnetite. However, the ferritchromite is the most common alteration phase observed in spinels elsewhere (Kimball 1990; Barnes 2000; Proenza et al. 2004; Farahat 2008; Aswad et al. 2011; Gervilla et al. 2012; Colas et al. 2014, 2016; Bhat et al. 2017b). Based on the earlier studies, the origin of ferritchromite is related to metamorphic and/or hydrothermal processes. According to Bliss and MacLean (1975) and Barnes (2000) ferritchromite is produced by the reaction of pristine spinel cores with magnetite rims during prograde metamorphism of the host serpentinised ultramafic rocks.
Likewise, Evans and Frost (1975) concluded that the $\mathrm{Cr}$ content of spinels increases with an increase in grade of the amphibolite facies. On the other hand, the results obtained by Burkhard (1993) suggest the opposite trend, and Roeder (1994), Gervilla et al. (2012) and Colas et al. (2014) showed ferritchromite to be the product of a reaction between Cr-spinels and chlorite from host rocks. Hence, the origin of ferritchromite remains an unsolved problem, the resolution of which is beyond the scope of this paper. However, both the models discretely assume that the Cr-spinel cores represent relic primary chromite that remained unaffected by the metamorphism.

Magnetite formation along fractures and rims (figure 2c and d) is the result of $\mathrm{Mg}^{2+}$ and $\mathrm{Fe}^{2+}$ cation exchange between spinels and coexisting silicates, particularly olivine (Barnes 2000; Karipi et al. 2007; Farahat 2008) which in turn changes into serpentine (Bhat et al. 2019a). In studied peridotites, the olivine and pyroxene minerals are highly magnesian i.e., $\mathrm{Fo}_{90-92}$ and $\mathrm{En}_{91-93}$, 
respectively (Bhat et al. 2019a); therefore, limited amounts of $\mathrm{Fe}$ are released on their hydration. The activity of the low-fluid-rock ratio during metamorphism may be inferred because of the common preservation of $\mathrm{Cr}$-spinel core compositions in the studied peridotites. By the diffusive replacement of $\mathrm{Mg}^{2+}$ with $\mathrm{Fe}^{2+}$ in the spinel structure, the ferritchromite and magnetite in studied peridotites show higher $\mathrm{Cr}^{3+} \#$ and $\mathrm{Fe}^{3+} \#$ but lower $\mathrm{Mg}^{2+} \#$ as compared to Cr-spinel core compositions (figure 4). This chemical discrepancy is due to preferential retention of $\mathrm{Cr}$ in unaltered $\mathrm{Cr}$-spinel cores while its alteration provides $\mathrm{Mg}$ for secondary spinels (Kimball 1990; Karipi et al. 2007). Although the compositional differences between the primary $\mathrm{Cr}$-spinel and secondary spinel, i.e., ferritchromite are small (figure 3) their prominent optical/chemical boundary advocates are controlled by a miscibility gap (Barnes 2000; Proenza et al. 2004; Arai et al. 2006; Farahat 2008).

The possibility of alteration of the primary spinel composition of the mantle origin is believed to be recognised easily by their marked increase of $\mathrm{Fe}^{3+} \#$ (Arai et al. 2006). In the present study, the primary Cr-spinels are characterised by $\mathrm{Cr}^{3+} \#(0.5-0.6)$ and $\mathrm{Fe}^{3+} \#$ (0.01-0.13), whereas secondary spinels i.e., ferritchromite have $\mathrm{Cr}^{3+} \#(0.8-0.9)$ and $\mathrm{Fe}^{3+} \#$ (0.5-0.6). These secondary spinels have chemical composition within the range of spinels from mantle peridotites and podiform chromites (Arai and Yurimoto 1994; Roeder 1994). With respect to the global $\mathrm{Cr}-\mathrm{Al}$ spinel trends, their compositions plot at the high $\mathrm{Cr}^{3+} \#$ and low $\mathrm{Mg}^{2+} \#$ ends in $\mathrm{Mg}^{2+} \#$ vs. $\mathrm{Cr}^{3+} \#$ and $\mathrm{Mg}^{2+} \#$ vs. $\mathrm{Fe}^{3+} \#$ spaces (figure 4), respectively (Barnes and Roeder 2001). The same results were observed by Arai et al. (2006) while studying Cr-spinels of serpentinised harzburgites and chromitites from Rayat area of northeastern Iraq. Thus, the present study suggests that while interpreting high $\mathrm{Cr}^{3+} \#$ Cr-spinels of mantle composition in altered rocks, caution is needed because for petrogenetic interpretation only primary Cr-spinels give paramount results.

Metamorphism of greenschist to lower amphibolite facies substantially modifies the primary spinel composition through infiltrating metamorphic fluids (Wylie et al. 1987; Barnes 2000). In spinels, the Cr-spinel core compositions equilibrated with ferritchromite and/or magnetite are usually attributed to greenschist compared to lower amphibolite facies metamorphism (Barnes 2000; Kapsiotis et al. 2007; Farahat 2008; Aswad et al. 2011). The relative proportion of trivalent ions i.e., $\mathrm{Cr}^{3+}, \mathrm{Al}^{3+}$ and $\mathrm{Fe}^{3+}$ in spinels is not modified up to lower amphibolite metamorphic grade and therefore can be used to estimate the metamorphic grade experienced by the host peridotites (Barnes 2000). Barnes (2000) also suggested that the metamorphism effectively controls $\mathrm{Mg}^{2+}$ \# of spinels. Peridotites experienced greenschist to lower amphibolite facies metamorphism possess spinels with $\mathrm{Mg}^{2+}$ \# ranging from 0.4 to 0.7; however, higher amphibolite grade rocks have $\mathrm{Mg}^{2+} \#<0.35$ (Barnes 2000; Farahat 2008). $\mathrm{Mg}^{2+}$ \# in the studied Cr-spinel ranges from 0.5 to 0.6 , reflecting green schist grade of metamorphism.
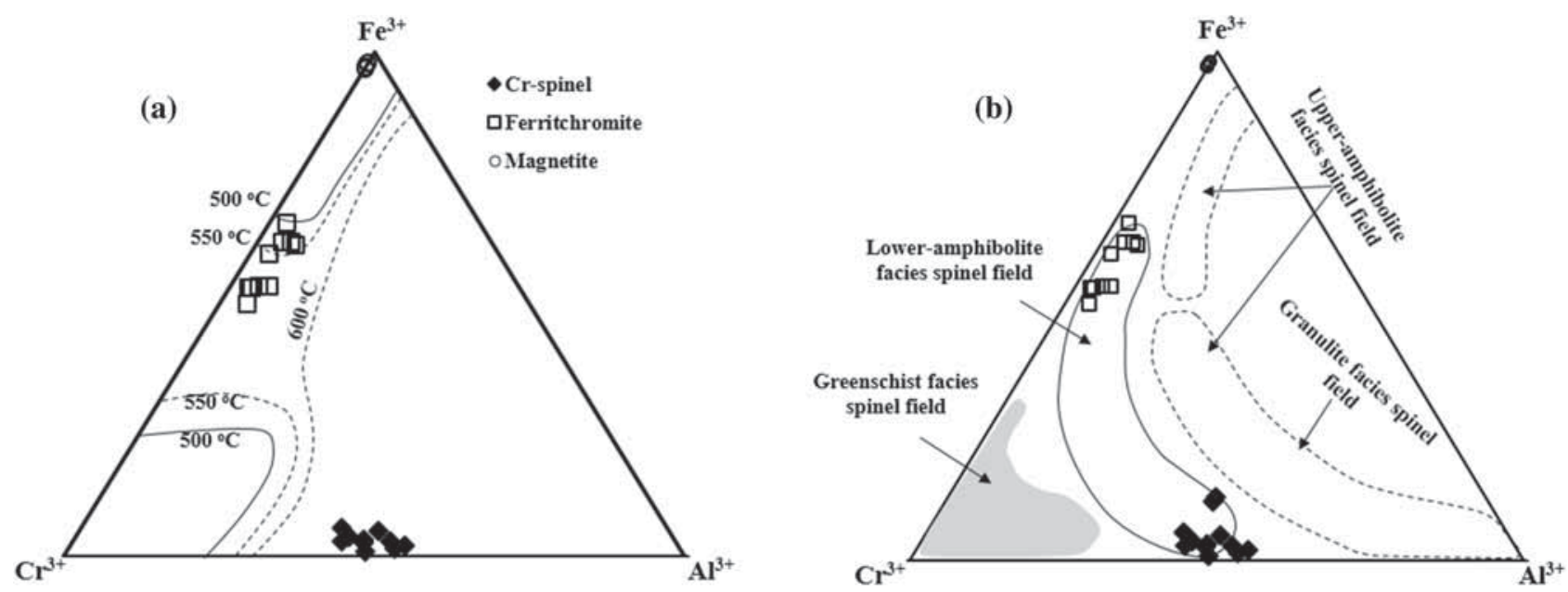

Figure 6. Compositional changes in spinels from Suru Valley peridotites (Cr-spinel, ferritchromite and magnetite) expressed in a triangular $\mathrm{Cr}^{3+}-\mathrm{Fe}^{3+}-\mathrm{Al}^{3+}$ plot after Barnes (2000): (a) studied spinel compositions compared with spinel stability fields after Sack and Ghiorso (1991) and (b) studied spinel compositions compared with spinel compositional fields from different metamorphic facies after Evans and Frost (1975). 
Also, the primary $\mathrm{Cr}$-content is retained in Cr-spinels equilibrated below $\sim 500-550^{\circ} \mathrm{C}$ stability limit but their $\mathrm{Mg}^{2+}$ \# is substantially lowered by $\mathrm{Fe}^{2+}-\mathrm{Mg}^{2+}$ exchange with surrounding silicates (Farahat 2008). The chemical composition of analysed spinels (i.e., Cr-spinel, ferritchromite and magnetite) from Suru Valley peridotites in relation to metamorphic temperature conditions is plotted on a triangular $\mathrm{Fe}^{3+}-\mathrm{Cr}^{3+}-\mathrm{Al}^{3+}$ diagram (figure 6a). In this diagram the Cr-spinel core composition plots outside these stability limits reflecting primary spinel compositions not being affected by metamorphism; however, ferritchromite and magnetite plots below $600^{\circ} \mathrm{C}$ stability limit indicate secondary compositions. Along grain boundaries and through cracks, magnetite was formed at lower temperature because of the readily exchange of $\mathrm{Fe}$ from host peridotite silicates e.g., olivine during serpentinisation (Gahlan et al. 2006). In mantle peridotites pure magnetite rims with limited $\mathrm{Cr}$ solubility, implying magnetite growth well below $500^{\circ} \mathrm{C}$ (Barnes 2000). The studied magnetite rims have substantial amounts of $\mathrm{Cr}$ concentration (0.05-1.66 wt\%; table 2) and thus reflecting magnetite growth well below $500^{\circ} \mathrm{C}$ stability limit as shown in figure 6(a).

Also, the analysed spinel chemical composition is plotted on a triangular $\mathrm{Fe}^{3+}-\mathrm{Cr}^{3+}-\mathrm{Al}^{3+}$ diagram, together with the spinel compositional fields from different metamorphic facies (figure 6b), where spinel compositional changes have been recorded with increasing metamorphic grade (Evans and Frost 1975; Frost 1991; Barnes and Roeder 2001). In this diagram, the altered spinel compositions characterised by lower $\mathrm{Al}$ content plot along the $\mathrm{Cr}-\mathrm{Fe}^{3+}$ joint and are typical of spinels altered at lower temperatures (Roeder 1994; Proenza et al. 2004). As shown in figure 6(b), the altered spinel compositions lie outside the upper-amphibolite to granulite facies spinel compositional field; however, the plot within the lower-amphibolite to the greenschist facies compositional field is similar to peridotites that have experienced low-PT metamorphism (Proenza et al. 2004; Colas et al. 2014; Bhat et al. 2017b). This interpretation is also favoured by the chemical composition of relic primary Cr-spinels and the whole-rock chondrite normalised rare earth element distribution patterns of the host peridotites (Bhat et al. 2019a). Similar geochemical characteristics have been observed in other Tethyan ophiolites that have not experienced eclogite facies metamorphism e.g., Iti and Kallidromon (Pindos) ophiolite, central Greece (Karipi et al. 2007), ophiolites of CED of Egypt (Farahat 2008), Serpentinites of Tidding Suture Zone, eastern Himalaya (Singh and Singh 2011) and Shergol ophiolitic peridotites, western Ladakh (Bhat et al. 2017b).

According to Barnes (2000) and Kapsiotis et al. (2007), due to greenschist to lower amphibolite grade metamorphism, Cr-spinels of mantle peridotites alter to magnetite and/or ferritchromite along grain margins and fractures as these are the only sites for metamorphic fluid interaction. The complete replacement of primary Cr-spinel grains with magnetite commonly occurs at mid to higher amphibolite grade metamorphism of host peridotites (Farahat 2008). In studied peridotites,

\section{Increasing grade of metamorphism}

Primary unaltered Cr-spinel

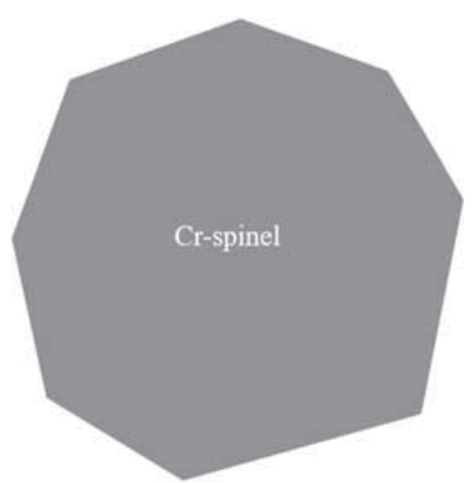

Greenschist facies metamorphism

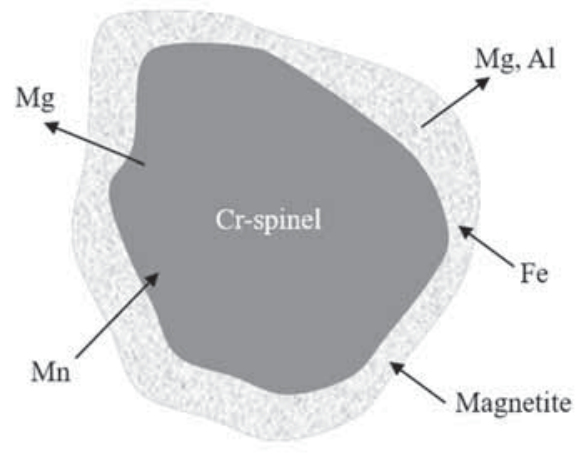

Greenschist-lower amphibolite facies metamorphism

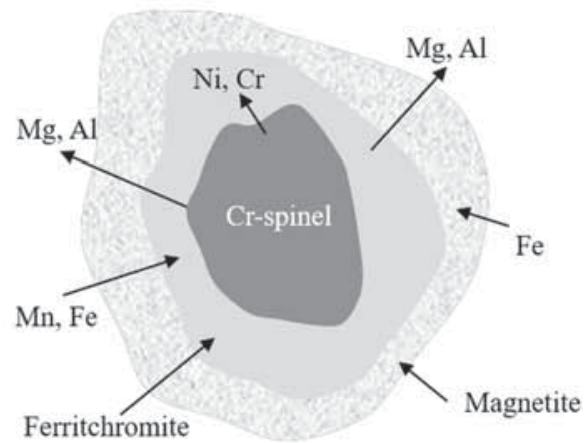

Figure 7. Schematic illustration of chemical changes in the primary Cr-spinel of Suru Valley peridotites during secondary alteration and metamorphism. The extent of element exchange is noted with arrows. 
the primary Cr-spinel composition is mantled by magnetite rims and/or ferritchromite, thus provides the textural indication for transitional greenschist to lower amphibolite facies metamorphism experienced by the host peridotites. The higher metamorphic conditions such as midamphibolite or granulite grade have not been achieved by the host peridotites because of the absence of complete replacement of Cr-spinel grains with magnetite compositions. Therefore, on the basis of the present spinel mineral chemistry the metamorphic conditions experienced by Suru Valley ophiolite peridotites are transitional greenschist to lower amphibolite facies consistent with an estimated metamorphic equilibration temperature of $\sim 500-600^{\circ} \mathrm{C}$ (figure 6a). Further, in a highpressure metamorphic environment, the degree of fluid-rock interaction is not pervasive (Cartwright and Barnicoat 1999). Also, the high-pressure metamorphism induces a local fluid flow at low water-rock ratios, therefore displays a closedsystem behaviour (Fruh-Green et al. 2001). Accordingly, we hesitantly suggest that under high-pressure conditions there is no resetting of the primary igneous composition of Cr-spinels. Therefore, the main alteration products observed in the Suru Valley peridotite spinels are the consequences of a low- $P$ and $T$ metamorphic alteration.

The chemical changes in primary Cr-spinel grains of Suru Valley peridotites during metamorphism with element exchange noted with arrows are shown in figure 7 . The compositional data show that $\mathrm{Fe}$ and to a less extent $\mathrm{Mn}$ are introduced into the Cr-spinel, whereas $\mathrm{Al}, \mathrm{Mg}$ and $\mathrm{Cr}$ of the Cr-spinel show outward diffusion during metamorphism. This results in a decrease in $\mathrm{Mg} /$ $\left(\mathrm{Mg}+\mathrm{Fe}^{2+}\right)$ and an increase in $\mathrm{Cr} /(\mathrm{Cr}+\mathrm{Al})$ of the magnetite compared to the unaltered $\mathrm{Cr}$-spinel core. Although, $\mathrm{Mn}^{2+}$ usually follows $\mathrm{Fe}^{2+}$, the ionic radius of $\mathrm{Mn}^{2+}(0.91 \AA)$ is much larger than that of $\mathrm{Fe}^{2+}(0.83 \AA)$ and $\mathrm{Mg}^{2+}(0.78 \AA)$, its ionic potential is relatively low and hence it is more susceptible to leaching by weakly acidic solutions (Economou-Elipoulos 2003). The studied ferritchromite with high-Mn content $(\mathrm{MnO}$ ranges from 1.77 to $4.37 \mathrm{wt} \%$ ) is due to the ability of the Cr-spinel to act as a favourable Mn-receptor during metamorphism as the secondary silicates (e.g., serpentine) accommodate less $\mathrm{Mn}$ than their igneous precursors (Deer et al. 1992). Therefore, the availability of $\mathrm{Mn}^{2+}$ in solution may be the major controlling factor for the incorporation of
$\mathrm{Mn}$ in the lattice of ferritchromite and to some extent Cr-spinel (Sack and Ghiorso 1991; Farahat 2008). This is the reason for the significant $\mathrm{Mn}$ enrichment up to 4.37 and $2.23 \mathrm{wt} \%$, respectively, in ferritchromite and the Cr-spinel in the Suru Valley ophiolite peridotites. Similar explanation was given by Singh and Singh (2011) for the spinels from the Tidding Suture Zone, eastern Himalaya.

\section{Acknowledgements}

The first author would like to thank Council of Scientific and Industrial Research (CSIR), New Delhi for providing the financial assistance in the form of Senior Research Fellowship (Grant No. 09/251(0057)/2014-EMR-I). Also, thanks Prof Shakil Ahmad Romshoo, Head, Department of Earth Sciences, University of Kashmir for giving permission to publish this work. Help extended by Prof N V Chalapathi Rao for carrying out Electron Probe Micro Analyses (EPMA) at the Banaras Hindu University, Varanasi is highly acknowledged.

\section{References}

Abdel-Karim A M, Ali S, Helmy H M and El-Shafei S A 2016 Fore-arc setting of the Gerf ophiolite, Eastern Desert, Egypt: Evidence from mineral chemistry and geochemistry of ultramaftes; Lithos 263 52-65.

Abdel-Karim A M, Ali S and El-Shafei S A 2018 Mineral chemistry and geochemistry of ophiolitic metaultramafics from Um Halham and Fawakhir, Central Eastern Desert, Egypt; Int. J. Earth Sci. 107 2337-2355.

Ahmad T, Tanaka T, Sachan H K, Islam R and Khanna P P 2008 Geochemical and isotopic characteristics on the age and origin of the Nidar Ophiolitic Complex, Ladakh, India: Implications for the Neo-Tethyan subduction along the Indus suture zone; Tectonophys. 451 206-224.

Ahmed A H, Arai S and Attia A 2001 Petrological characteristics of podiform chromitites and associated peridotites of the Pan African Proterozoic ophiolite complexes of Egypt; Miner. Deposita 36 72-84.

Ahmed A H, Arai S, Abdel-Aziz Y M and Rahimi A 2005 Spinel composition as a petrogenetic indicator of the mantle section in the Neoproterozoic Bou Azzer ophiolite, AntiAtlas, Morocco; Precamb. Res. 138 225-234.

Ahmed A H, Gharib M E and Arai S 2012 Characterization of the thermally metamorphosed mantle crust transition zone of the Neoproterozoic ophiolite at Gebel Mudarjaj, south Eastern Desert, Egypt; Lithos 142-143 67-83.

Aitchison J C, Badengzhu Davis A M, Liu J B, Luo H, Malpas J G, McDermid I R C, Wu H Y, Ziabrev S V and Zhou M F 2000 Remnants of a Cretaceous intra-oceanic subduction system within the Yarlung-Zangbo suture (southern Tibet); Earth Planet. Sci. Lett. 183 231-244. 
Aitchison J C, Davis A M, Badengzhu B and Luo H 2002 New constraints on the India-Asia collision: The Lower Miocene Gangrinboche conglomerates, Yarlung Tsangpo suture zone, SE Tibet; J. Asian Earth Sci. 21 251-263.

Aitchison J C, Ali J R and Davis A M 2007 When and where did India and Asia collide?; J. Geophys. Res. 112 B5.

Anzil P A, Guereschi A B and Martino R D 2012 Mineral chemistry and geothermometry using relic primary minerals in the La Cocha ultramafic body: A slice of the upper mantle in the Sierra Chica of Cordoba, Sierras Pampeanas, Argentina; J. South Am. Earth Sci. 40 38-52.

Arai S 1978 Formation of the chlorite corona around chromian spinel in peridotite and its significance; Geos. Rep. Shizuoka Univ. 3 9-15.

Arai S 1992 Chemistry of chromian spinel in volcanic rocks as a potential guide to magma chemistry; Mineral. Mag. 56 $173-184$.

Arai S 1994a Characterization of spinel peridotites by olivinespinel compositional relationships: Review and interpretation; Chem. Geol. 113 191-204.

Arai S 1994b Compositional variation of olivine-chromain spinel in Mg-rich magmas as a guide to their residual spinel peridotites; J. Volcanol. Geoth. Res. 59 279-294.

Arai S and Yurimoto H 1994 Podiform chromitites of the TariMisaka ultramafic complex, southwestern Japan, as mantlemelt interaction products; Econ. Geol. 89 1279-1288.

Arai S, Shimizu Y, Ismail S A and Ahmad A H 2006 Low T formation of high-Cr spinel with apparently primary chemical characteristics within podiform chromitite from Rayat, northeastern Iraq; Mineral. Mag. 70 499-508.

Arif M and Jan M Q 2006 Petrotectonic significance of the chemistry of chromite in the ultramafic-mafic complexes of Pakistan; J. Asian Earth Sci. 27 628-646.

Aswad K J, Aziz N R and Koyi H A 2011 Cr-spinel compositions in serpentinites and their implications for the petrotectonic history of the Zagros Suture Zone Kurdistan Region, Iraq; Geol. Mag. 148 802-818.

Barnes S I 2000 Chromite in Komatiites, II. Modification during greenschist to mid amphibolite facies metamorphism; J. Petrol. 41 387-409.

Barnes S J and Roeder P L 2001 The range of spinel compositions in terrestrial mafic and ultramafic rocks; J. Petrol. 42 2279-2302.

Bhat I M, Ahmad T and Subba Rao D V 2017a Geochemical characterization of serpentinized peridotites from the shergol ophiolitic slice along the Indus Suture Zone (ISZ), Ladakh Himalaya, India; J. Geol. 125 501-513.

Bhat I M, Ahmad T and Subba Rao D V 2017b Compositional variability of spinel-group minerals from the Shergol serpentinized peridotites along Indus suture zone, Ladakh Himalaya (India): Constraints on tectonomagmatic history; Chem. Erde Geochem. 77 587-595.

Bhat I M, Ahmad T and Subba Rao D V 2018 Complex protolith origin of serpentinized peridotites from the Shergol ophiolitic slice north-western Ladakh Himalaya, Jammu and Kashmir, India; J. Appl. Geochem. 20 213-219.

Bhat I M, Ahmad T and Subba Rao D V 2019a Origin and evolution of Suru valley ophiolite peridotite slice along Indus suture zone, Ladakh Himalaya, India: Implications on melt-rock interaction in a subduction-zone environment; Chem. Erde Geochem., https://doi.org/10.1016/j.chemer. 2018.10.003.
Bhat I M, Ahmad T and Subba Rao D V 2019b The tectonic evolution of the Dras arc complex along the Indus suture zone, western Himalaya: Implications for the Neo-Tethys ocean geodynamics; J. Geodyn. 124 52-66.

Bliss N W and MacLean W H 1975 The paragenesis of zoned chromite from central Manitoba; Geochim. Cosmochim. Acta 39 973-990.

Bortolotti V and Principi G 2005 Tethyan ophiolites and Pangea break-up; Isl. Arc 14 442-470.

Brookfield M E and Reynolds P H 1981 Late Cretaceous emplacement of the Indus suture zone ophiolitic melanges and an eocene-oligocene magmatic arc on the northern edge of the Indian plate; Earth Planet. Sci. Lett. 55 157-162.

Buckman S, Aitchison J C, Nutman A P, Bennett V C, Saktura W M, Walsh M J, Kachovich S and Hidaka H 2018 The Spongtang Massif in Ladakh, NW Himalaya: An early Cretaceous record of spontaneous, intra-oceanic subduction initiation in the Neotethys; Gondwana Res. 63 226-249.

Burkhard D J M 1993 Accessory chromium spinels: Their coexistence and alteration in serpentinites; Geochim. Cosmochim. Acta 57 1297-1306.

Cartwright I and Barnicoat A C 1999 Stable isotope geochemistry of Alpine ophiolites: A window to ocean-floor hydrothermal alteration and constraints on fluid-rock interaction during high-pressure metamorphism; Int. J. Earth Sci. 88 219-235.

Clift P, Hannigan R, Blusztajn J and Draut A E 2002 Geochemical evolution of the Dras-Kohistan Arc during collision with Eurasia: Evidence from the Ladakh Himalaya, India; Isl. Arc 11 255-273.

Colas V, Gonzalez-Jimenez J M, Griffin W L, Fanlo I, Gervilla F, O'Reilly S Y, Pearson N J, Kerestedjian T and Proenza J A 2014 Fingerprints of metamorphism in chromite: New insights from minor and trace elements; Chem. Geol. 389 137-152.

Colas V, Padron-Navarta J A, Gonzalez-Jimenez J M, Griffin W L, Fanlo I, O'Reilly S Y, Gervilla F, Proenza J A, Pearson N J and Escayola M P 2016 Compositional effects on the solubility of minor and trace elements in oxide spinel minerals: Insights from crystal-crystal partition coefficients in chromite exsolution; Am. Mineral. 101 1360-1372.

Dai J, Wang C, Hebert R, Santosh M, Li Y and Xu J 2011 Petrology and geochemistry of peridotites in the Zhongba ophiolite, Yarlung Zangbo Suture zone: Implications for the early Cretaceous intraoceanic subduction zone within the Neo-Tethys; Chem. Geol. 288 133-148.

Dai J, Wang C, Polat A, Santosh M, Li Y and Ge Y 2013 Rapid forearc spreading between 130 and 120 Ma: Evidence from geochronology and geochemistry of the Xigaze ophiolite, southern Tibet; Lithos 172-173 1-16.

Deer W A, Howei R A and Zussman J 1992 The rock forming minerals; 2nd edn, Longmans, London, 696p.

Deitrich V J, Frank W and Honegger K 1983 A JurassicCretaceous island arc in the Ladakh-Himalayas; J. Volcanol. Geotherm. Res. 18 405-433.

Deschamps F, Guillot S, Godard M, Chauvel C, Andreani M and Hattori K 2010 In situ characterization of serpentinites from forearc mantle wedges: Timing of serpentinization and behavior of fluid mobile elements in subduction zones; Chem. Geol. 269 262-277.

Deschamps F, Godar M, Guillot S and Hattori K 2013 Geochemistry of subduction zone serpentinites: A review; Lithos 178 96-127. 
Dick H J B and Bullen T 1984 Chromian spinel as a petrogenetic indicator in abyssal and alpine type peridotites and spatially associated lavas; Contrib. Mineral. Petrol. 86 54-76.

Dilek Y and Furnes H 2009 Structure and geochemistry of Tethyan ophiolites and their petrogenesis in subduction rollback systems; Lithos 113 1-20.

Economou-Elipoulos M 2003 Apatite and Mn, Zn, Co-enriched chromite in Ni-laterites of northern Greece and their genetic significance; J. Geochem. Exp. 80 41-54.

Evans B W and Frost B R 1975 Chrome-spinel in progressive metamorphism - a preliminary analysis; Geochim. Cosmochim. Acta 39 959-972.

Farahat E S 2008 Chrome-spinels in serpentinites and talc carbonates of the El Ideid-El Sodmein District, central eastern desert, Egypt: Their metamorphism and petrogenetic implications; Chem. Erde Geochem. 68 193-205.

Farahat E S, Hoinkes G and Mogessie A 2011 Petrogenetic and geotectonic significance of neoproterozoic suprasubduction mantle as revealed by the Wizer ophiolite complex, central eastern desert, Egypt; Int. J. Earth Sci. 100 1433-1450.

Frank W, Gansser A and Trommsdorff V 1977 Geological observations in the Ladakh area (Himalayas) - a preliminary report; Schweiz. Mineral. Petrograph. Mitt. 57 89-113.

Frost B R 1991 Stability of oxide minerals in metamorphic rocks; In: Oxide Minerals: Petrologic and Magnetic Significance (ed.) Lindsley D H, Rev. Miner. 25 469-487.

Fruh-Green G L, Scambelluri M and Vallis F 2001 O-H isotope ratios of high pressure ultramafic rocks: Implications for fluid sources and mobility in the subducted hydrous mantle; Contrib. Mineral. Petrol. 141 145-159.

Gahlan H A, Arai S, Ahmed A H, Ishida Y, Abdel Aziz Y M and Rahim A 2006 Origin of magnetite veins in serpentinite from the late proterozoic Bou-Azzer ophiolite, anti-Atlas, Morocco: An implication for mobility of iron during serpentinization; J. Afr. Earth Sci. 46 318-330.

Gansser A 1964 The geology of the Himalayas; Wiley Interscience, New York, 289p.

Gansser A 1980 The significance of the Himalaya suture zone; Tectonophys. 62 37-40.

Gervilla F, Padron-Navarta J, Kerestedjian T, Sergeeva I, González-Jiménez J and Fanlo I 2012 Formation of ferrian chromite in podiform chromitites from the Golyamo Kamenyane serpentinite, Eastern Rhodopes, SE Bulgaria: A two-stage process; Contrib. Mineral. Petrol. 164 1-15.

Hall R 1997 Cenozoic plate tectonic reconstructions of SE Asia; Geol. Soc. London, Spec. Publ. 126 11-23.

Honegger K, Dietrich V, Frank W, Gansser A, Thoni M and Trommsdorf V 1982 Magmatic and metamorphism in the Ladakh Himalayas (the Indus-Tsangpo suture zone); Earth Planet. Sci. Lett. 60 253-292.

Honegger K, Le Fort P, Mascle G and Zimmermann J L 1989 The blueschists along the Indus suture zone in Ladakh, NW Himalaya; J. Metamorph. Geol. 7 57-72.

Irvine T N 1965 Chromian spinel as a petrogenetic indicator; part 1, theory; Can. J. Earth Sci. 2 648-672.

Irvine T N 1967 Cr-spinel as a petrogenetic indicator, part 2 Petrological applications; Can. J. Earth Sci. 4 71-103.

Jonnalagadda M K, Karmalkar N R, Benoit M, Gregoire M, Duraiswami R A, Harshe S and Kamble S 2019 Compositional variations of chromian spinels from peridotites of the Spontang ophiolite complex, Ladakh, NW Himalayas,
India: Petrogenetic implications; Geosci. J., https://doi. org/10.1007/s12303-019-0001-3.

Kamenetsky V S, Crawford A J and Meffre S 2001 Factors controlling chemistry of magmatic spinel: An empirical study of associated olivine, Cr-spinel and melt inclusions from primitive rocks; J. Petrol. 42 655-671.

Kapsiotis A I, Tsikouras B T, Grammatikopoulos T, Karipi S $\mathrm{T}$ and Hatzipanagiotou K 2007 On the metamorphic modification of Cr-spinel compositions from the ultrabasic rocks of the Pindos ophiolite complex (NW Greece); Bull. Geol. Soc. Greece 40 781-793.

Karipi S, Tsikouras B and Hatzipanagiotou K 2007 Petrogenetic significance of spinel-group minerals from the ultramafic rocks of the Iti and Kallidromon ophiolite (Central Greece); Lithos 99 136-149.

Khalil A E S and Azer M K 2007 Supra-subduction affinity in the Neoproterozoic serpentinites in the Eastern Desert, Egypt: Evidence from mineral composition; J. Afr. Earth Sci. 49 136-152.

Khedr M Z and Arai S 2013 Origin of Neoproterozoic ophiolitic peridotites in south Eastern Desert, Egypt, constrained from primary mantle mineral chemistry; Mineral. Petrol. 107 807-828.

Khedr M Z, Arai S, Python M and Tamura A 2014 Chemical variations of abyssal peridotites in the central Oman ophiolite: Evidence of oceanic mantle heterogeneity; Gondwana Res. 25 1242-1262.

Khudeir A A 1995 Chromian spinel-silicate chemistry in peridotite and orthopyroxenite relics from ophiolitic serpentinites, Eastern Desert, Egypt; Bull. Fac. Sci. Assiut. Univ. 24 221-261.

Khudeir A A, El Haddad M A and Leake B E 1992 Compositional variation in chromite from the Eastern Desert; Mineral. Mag. 56 567-574.

Kimball K L 1990 Effects of hydrothermal alteration on the compositions of chromian spinels; Contrib. Mineral. Petrol. $105337-346$.

Maheo G, Bertrand H, Guillot S, Villa I M, Keller F and Capiez P 2004 The south Ladakh ophiolites (NW Himalaya, India): An intra-oceanic tholeiitic origin with implication for the closure of the Neo-Tethys; Chem. Geol. 203 273-303.

Maheo G, Fayoux X, Guillot S, Garzanti E, Capiez P and Mascle G 2006 Relics of an intra-oceanic arc in the SapiShergol mélange zone (Ladakh, NW, Himalaya, India): Implications for the closure of the Neo-Tethys ocean; J. Asian Earth Sci. 26 695-707.

Mevel C 2003 Serpentinization of abyssal peridotites at midocean ridges; C.R. Geosci. 335 825-852.

Moores E M, Kellogg L and Dilek Y 2000 Tethyan ophiolites, mantle convection and tectonic historical contingency: A resolution of the ophiolite conundrum; In: Ophiolites and Oceanic Crust: New Insights from Field Studies and Ocean Drilling Program (eds) Dilek Y, Moores E M, Elthon D and Nicolas A, Geol. Soc. Am. Spec. Publ. 349 3-12.

Niu Y 2004 Bulk-rock major and trace element compositions of abyssal peridotites: Implications for mantle melting, melt extraction and post-melting processes beneath mid-ocean ridges; J. Petrol. 45 2423-2458.

Obeid M A, Khalil A E S and Azer M K 2016 Mineralogy, geochemistry and geotectonic significance of the Neoproterozoic ophiolite of Wadi Arais area, south Eastern Desert, Egypt; Int. Geol. Rev. 58 687-702. 
Paulick H, Bach W, Godard M, De Hoog J C M, Suhr G and Harvey J 2006 Geochemistry of abyssal peridotites (midAtlantic ridge, $15^{\circ} 20^{\prime} \mathrm{N}$, ODP Leg 209): Implications for fluid/rock interaction in slow spreading environments; Chem. Geol. 234 179-210.

Proenza J A, Ortega-Gutierrez F, Camprubi A, Tritlla J, Elias-Herrera M and Reyes-Salas M 2004 Paleozoic serpentinite-enclosed chromitites from Tehuitzingo (Acatlan complex, southern Mexico): A petrological and mineralogical study; J. S. Am. Earth Sci. 16 649-666.

Radhakrishna T, Divakara Rao V and Murali A V 1984 Geochemistry of Dras volcanic and the evolution of the Indus suture ophiolites; Tectonophys. 108 135-153.

Radhakrishna T, Divakara Rao V and Murali A V 1987 Geochemistry and petrogenesis of ultramafic and mafic plutonic rocks of the Dras ophiolitic mélange, Indus suture (northwest Himalaya); Earth Planet. Sci. Lett. 82 136-144.

Reuber I 1989 The Dras arc: Two successive volcanic events on eroded oceanic crust; Tectonophys. 161 93-106.

Reuber I, Montigny R, Thuizat R and Heitz A 1990 K/Ar ages of ophiolites and arc volcanics of the Indus suture zone: Comparison with other Himalaya-Karakorum data; $J$. Himal. Geol. 1 115-125.

Robertson A H F 2000 Formation of mélanges in the Indus Suture Zone, Ladakh Himalaya by successive subductionrelated, collisional and post-collisional processes during Late Mesozoic-Late Tertiary time; Geol. Soc. London, Spec. Publ. 170 333-374.

Roeder P L 1994 Chromite: From the fiery rain of chondrules to the Kilauea Iki lava lake; Can. Mineral. 32 729-746.

Sachan H K 2001 Supra-subduction origin of the Nidar Ophiolitic sequence, Indus Suture Zone, Ladakh, India: Evidence from mineral chemistry of upper mantle rocks; Ofioliti 26 23-32.

Sack R O and Ghiorso M S 1991 Chromian spinels as petrogenetic indicators: Thermodynamic and petrological applications; Am. Mineral. 76 827-847.
Searle M P, Windley B F, Coward M P, Cooper D J W, Rex D C, Tingdong L, Xuchang X, Jan M Q, Thakur V C and Kumar S 1987 The closing of Tethys and the tectonics of Himalaya; Geol. Soc. Am. Bull. 98 678-701.

Singh A K 2009 High-Al chromian spinel in peridotites of Manipur ophiolitic complex, Indo-Myanmar Orogenic Belt: Implication for petrogenesis and geotectonic setting; Curr. Sci. 96 973-978.

Singh A K and Singh R K B 2011 Zn and Mn rich chromespinels in serpentinite of Tidding Suture Zone, Eastern Himalaya and their metamorphism and genetic significance; Curr. Sci. 100 743-749.

Sinha A K and Mishra M 1992 Emplacement of the ophiolitic mélange along continental collision zone of Indus Suture Zone in Ladakh Himalaya; J. Himal. Geol. 3 179-189.

Sinha A K and Mishra M 1994 The existence of oceanic islands in the Neotethys: Evidence from Ladakh Himalaya, India; Curr. Sci. 67 721-727.

Srikantia S V and Razdan M L 1980 Geology of part of central Ladakh Himalaya with particular reference to Indus tectonic zone; J. Geol. Soc. India 21 523-545.

Uysal I, Yalcin Ersoy E, Karsli O, Dilek Y, Burhan Sadiklar M, Ottley C J, Tiepolo M and Meisel T 2012 Coexistence of abyssal and ultra-depleted SSZ type mantle peridotites in a Neo Tethyan ophiolite in SW Turkey: Constraints from mineral composition, whole-rock geochemistry (majortrace-REE-PGE), Re-Os isotope systematics; Lithos 132-133 50-69.

Veisinia A, Ebrahimi M, Mokhtari M A A, Ahmadian J and Azimzadeh A M 2018 Application of Cr-spinel mineral chemistry in petrogenetic evolution and tectonic setting of NE Kamyaran ophiolitic complex; Iranian J. Crystallogr. Mineral. 2645.

Wylie A G, Candela P A and Burke T M 1987 Compositional zoning in unusual Zn-rich chromite from the Sykeville district of Maryland and its bearing on the origin of the ferritchromite; Am. Mineral. 72 413-422. 